\author{
Julia Budka
}

\title{
HUMBOLDT UNIVERSITY NUBIAN EXPEDITION RIVERBANK GROUP: SUMMARY OF THREE SEASONS IN THE FOURTH CATARACT AREA $(2004-2006)^{1}$
}

The Northeast African Archaeology and Cultural Studies Seminar of the Humboldt University Berlin has been taking part in the Merowe Dam Archaeological Salvage Project at the Fourth Cataract in Northern Sudan since March 2004 (for general information on the campaign, cf. Hakem 1993; Paner 1998; Ahmed 2003). The Humboldt University Nubian Expedition (H.U.N.E.) is organized as two teams, one working on the mainland and one on the islands in the concession area. ${ }^{2}$ The following is a report on the activities of H.U.N.E. on the mainland from 2004 to $2006 .^{3}$

\section{Topographic Description Of The Con- CESSION AREA}

The southern end of H.U.N.E.'s concession area [Fig. 1] on the mainland is marked by Gebel Musa (Gabal Musa, also known as Gebel Kirbekān or Kirbekān Ridge) (Innes 1931: 188, Pl. XI), the site of the Battle of Kirbekān (al-Kirbikān) on 9 February 1885 [Fig. 2]. At the bend of the Nile immediately north of the village of Salamat (Sug al-Salamāt) lies the upstream end. The region is predominantly a mass of gebels, rocky hilltops and large stone boulders, especially in the areas from Gebel Musa up to Umm Meshera, between Kereiti and El-Debab, and northwards of Shellal (cf. general observations on the landscape of the Fourth Cataract by Donadoni 1990; Donadoni 1997; Welsby and Davies 2002: 36). There is practically no riverine area. Rocky outcrops and boulders coming down to the river characterize the landscape. But there are also sandy dunes like small islands between the rocky outcrops, e.g. near Umm Jaghor and El-Debab. In some areas, e.g. around Mushra (Mušr ${ }^{r}$ al-Hammir) and south

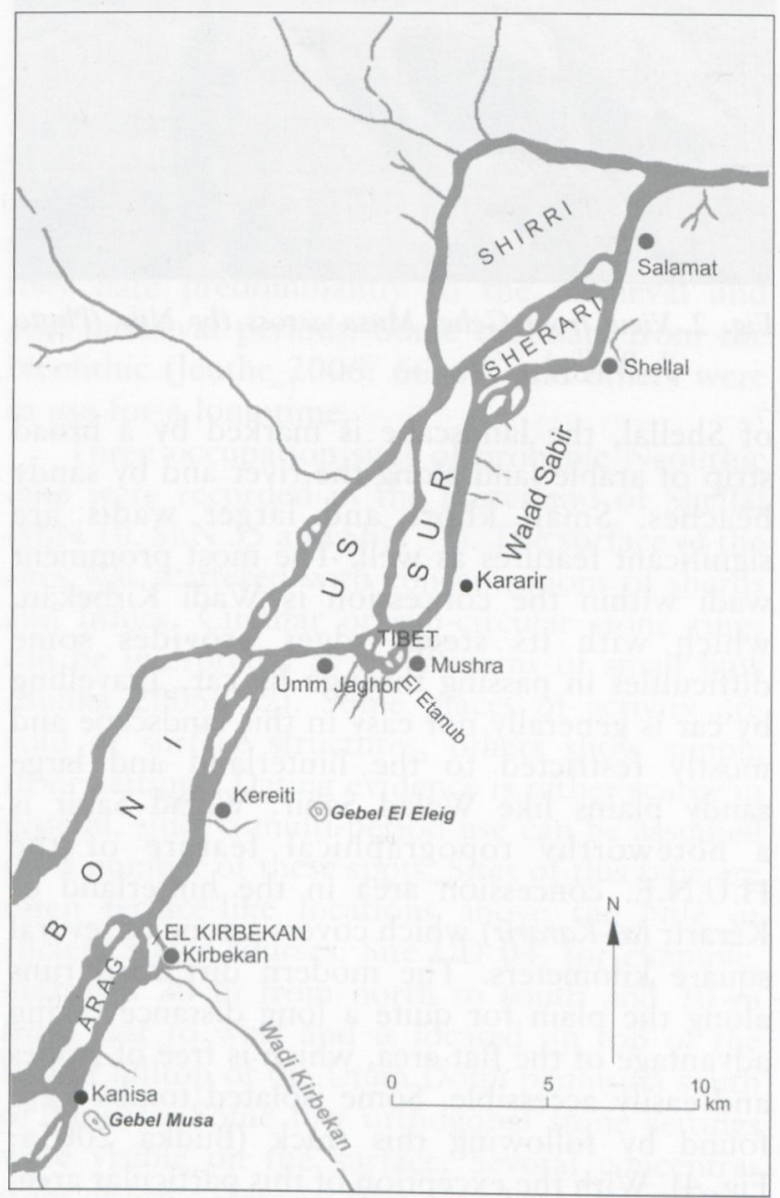

Fig. 1. Map of the H.U.N.E. concession (adapted after Säuberlich in Näser 2005)

\footnotetext{
${ }^{1}$ I am indebted to Frank Kammerzell for many useful comments on this paper.

2 Annual reports on H.U.N.E.'s activities were published in Der Antike Sudan; cf. Budka 2004c; 2005b; 2006 and Kammerzell 2004, as well as Näser 2004; 2005 and 2006 for the island concession.

${ }^{3}$ Many thanks go to all team members of the mission from Germany, Austria, Sudan and the Netherlands: Frank Kammerzell (project director), Julia Budka (archaeologist and field director 2004, 2005, 2006), Amel Suliman Badi (University of Khartoum, ethnological research, 2006), Jonas Beran (archaeologist, 2006), Karl Berbalk (camp \& water installation, 2005 and 2006), Dieter Eigner (architect, 2005 and 2006), Fawzi Hassan Wahid (NCAM, 2004), Thiqa Hassan (NCAM, 2005), Clara Jeuthe (archaeologist, lithics, 2005), Tim Karberg (archaeologist, 2005 and 2006), Rihab Khidir (NCAM, 2006), Uwe Sievertsen (archaeologist, pottery analysis, 2005), Nico Staring (archaeologist, 2006) and Petra Weschenfelder (archaeologist, ethnologist, 2006).
} 


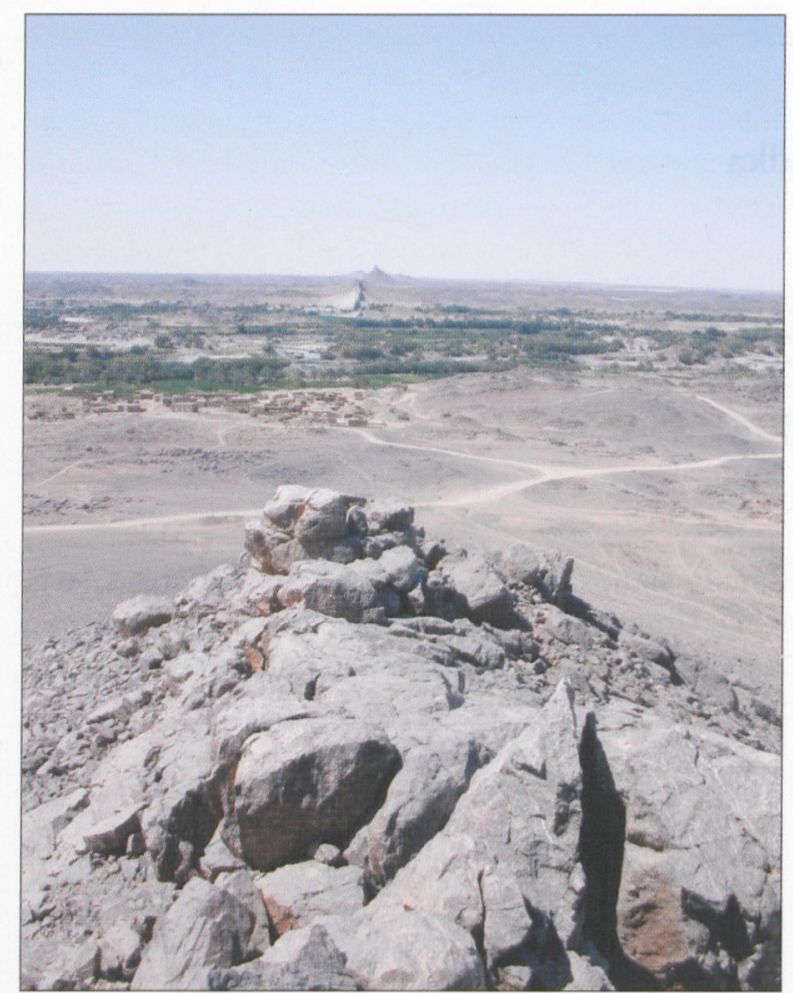

Fig. 2. View from Gebel Musa across the Nile (Photo J. Budka)

of Shellal, the landscape is marked by a broad strip of arable land along the river and by sandy beaches. Small khors and larger wadis are significant features as well. The most prominent wadi within the concession is Wadi Kirbekān, which with its steep ridges provides some difficulties in passing through by car. Travelling by car is generally not easy in this landscape and mostly restricted to the hinterland and large sandy plains like Walad Sabir. Walad Sabir is a noteworthy topographical feature of the H.U.N.E. concession area in the hinterland of Kerarir (al-Kararir) which covers a zone of several square kilometers. The modern dirt road runs along the plain for quite a long distance taking advantage of the flat area, which is free of stones and easily accessible. Some isolated tombs were found by following this track (Budka 2005a: Fig. 4). With the exception of this particular area, the H.U.N.E. survey on the mainland was conducted on foot.

\section{Sites, Finds And Monuments}

\subsection{Site nomenclature}

In 2004, a simple coding system involving general information about the location within the concession area was established for labeling recorded sites. Thus, the label includes the name of the nearest identified village and a number in sequence. The general areas used as abbreviations are in alphabetical order:

- Gezira (GEZ, one of the hamlets making up the village of Kirbekān) (Eigner 2006: 76-78) ${ }^{4}$

- Kirbekān (KIR, region ranging from the Gebel Musa up to the village of Kirbekān)

- Kereiti North (KN, strip along the Nile from Kereiti up to Umm Jaghor)

- Mushra South (MS, region south of Mushra up to El-Debab)

- Mushra North (MN, strip along the Nile up to Kararir)

- Sabir (SA, surroundings of a small hamlet)

- Shellal North (ShN, region between Shellal and Salamat)

- Shellal South (ShS, area south of Shellal up to Sabir)

- Salamat (SAL, hinterland of Salamat and the northern end of the concession area)

- Umm Domi (UD, small peninsula of Umm Domi) (Budka 2005a: 9)

- Umm Jaghor (UJ, surroundings of the village Umm Jaghor towards El-Debab)

- Umm Qatatia (UQ, part of the modern village of Kirbekān).

\subsection{Survey and excavation results}

The aims of the project were to survey the concession area, record archaeological sites and excavate selected ones. During the three seasons of work all of the concession area was successfully surveyed. Eight sites were excavated. They comprise two dome-grave cemeteries, four isolated graves, a church and a stone setting of unclear function. In addition, Dieter Eigner started in 2005 to study the modern architecture of the Manasir taking the village of Kirbekān as an example (Eigner 2005a; 2006). In 2006, the research design of this subproject was enlarged to include cultural anthropological fieldwork, which was undertaken by Petra Weschenfelder and Amel Badi (Weschenfelder 2006).

Concerning the topographical distribution of archaeological fieldwork, the Kirbekān region was investigated in the detail (six weeks of work, for details, see Budka 2005; Eigner 2005b; Sievertsen 2005). The survey yielded 585 sites, of which 354 are situated in the area called Kirbekān. Following is a list of the most common types of sites and their presumed dating:

- cemeteries (primarily tumuli — of different earthwork and stone setting types - and box graves, but also some isolated tombs, as well as dome graves and cairns, fissure graves and

${ }^{4}$ Six rock art stations were recorded within the modern village; for the layout and architecture of the village, see Eigner 2005a: 114-124. 
miscellaneous funerary remains like the socalled cist graves; ${ }^{5}$ thus comprising many different types and sizes with a timespan from a possible Neolithic through Kerma Ancien to Medieval times);

- places of occupation and settlements (most often medieval dwelling places but also Neolithic, as well as multi-period occupation sites were found, frequently situated on flat hilltops overlooking the river or above ancient Nile branches);

- isolated shelters and huts (mainly of medieval and/or post-medieval date, sometimes connected with rock art, especially with engravings depicting camels) (Budka 2004: 111-112);

- various stone settings, enclosures and rubble walls (many of them probably of quite recent date, "others may be of some antiquity") (Welsby 2003a: 123; cf. also Welsby 2005b: 6); - rock drawings (different motifs, dominated by camel and cattle; but also some giraffes, ostriches, equines, and goats as well as depictions of churches, ships and symbols), several Arabic rock graffiti, as well as three Greek rock inscriptions; (for the Greek inscriptions from Kirbekān, see Tsakos 2007);

- Christian church (KIR 257) including a medieval box grave cemetery (KIR 324) at the foot of Gebel Musa in the area of the village of El-Kanisa.

Table 1. Dating of the sites in the H.U.N.E. mainland concession

\begin{tabular}{lc}
\hline PERIOD & NUMBER OF SITES \\
\hline Early Khartoum/Neolithic & 8 \\
\hline Neolithic? & 3 \\
\hline Kerma & 62 \\
\hline Kerma? & 13 \\
\hline Terminal Kerma to Napatan & 19 \\
\hline Napatan & 4 \\
\hline (Late) Meroitic? & 2 \\
\hline post-Meroitic & 49 \\
\hline Medieval & 138 \\
\hline Medieval to post-Medieval & 153 \\
\hline post-Medieval & 17 \\
\hline Recent & 11 \\
\hline Multi-period & 22 \\
\hline Unclear & 84 \\
\hline
\end{tabular}

The span of time covered extends from the prehistoric (Paleolithic and Neolithic) to postMedieval times [Table 1]. The bulk of the surface material seems to belong to the Christian and Islamic periods. Neolithic material, including both pottery and lithics, is also quite common among the finds collected from the surface. For most of the sites (total of 501), a tentative dating can be proposed based on the surface finds and the morphology of aboveground structures. In the case of 84 sites a specific period cannot be indicated as yet; some of these seem to belong to the Neolithic period, others to the Kerma horizon, and a small number might be of recent date. Rock art is not easily dated; most of the rock art sites are categorized here as "Medieval to post-Medieval” (see below).

\subsubsection{Settlements and remains of occupation}

A considerable number of occupation scatters and workplaces were discovered. According to the surface finds - especially pottery and lithics (on the lithics from the survey, see Jeuthe 2005) they date predominantly to the medieval and post-medieval periods. Some originate from the Neolithic (Jeuthe 2006: 66-69) and others were in use for a long time.

Three occupation sites of probable Neolithic date were recorded in the hinterland of Shellal (ShN 10, ShN 35 and ShN 37). The surface of the sites was scattered with concentrations of sherds and lithics. Circular or sub-circular stone rings can be interpreted as the remains of small huts (Budka 2006: 52). Some places of activity are void of surface structures, others show simple stone settings. Dating evidence is rather scarce in general, since a multi-period use can be assumed for a number of these spots. Sites of this type are often terrace-like locations above the Nile or ancient water courses. Site UD 04, for example, measures $20 \mathrm{~m}$ from north to south and $10 \mathrm{~m}$ from east to west and is located on top of the largest hilltop of the Umm Domi peninsula south of Mushra. Some low orthogonal stone settings were visible on the surface. Several concentrations of lithic material (flakes and tools) as well as ceramics were found on the surface and suggest a multi-period use of the site (Budka 2005a: 14).

A considerable amount of small shelters and artifact scatters (lithics and pottery) were found around hilltops and on rocky outcrops (e.g. KN 041, KN 019, KN 010), sometimes comprising circular or rectangular features and stone settings of a still unknown function (Paner 2003a: 178, Figs 16 and 17). A typical example of this

5 The latter dubbed 'tunnel' graves by Welsby, see Welsby 2005b: 5-6, Pl. 5, and infra. 
type of site is a large plateau on top of a gebel in the hinterland of El-Debab. It revealed several small places on the rocky surface, which were littered with flakes, very few sherds and some stone settings (site MS 039). The natural rock was used as shelter and in addition, some large boulders were connected with rubble-like walls. The main feature seems to be a small stone-ring ( $2 \mathrm{~m}$ in diameter) in the southeastern corner of the plateau where the surface was covered with some flint flakes. Large granite boulders protect the place against the wind, which in this area is usually blowing from the north.

The identification of places of settlement becomes difficult in the case of sites originating in the Kerma, Napatan and Meroitic periods. Again, there are some possible candidates among the sites recorded, but only excavation has the potential to prove these dates. ${ }^{6}$ Due to the lack of time, no such sites were excavated in the H.U.N.E. concession area and their nature and date can only be assumed by comparison with similar sites excavated in neighboring concessions. Compared with earlier and later periods, the evidence for the first millennium $\mathrm{BC}$ is generally scarce within the region. This picture is probably due to major problems with identifying Kushite sites by means of survey. In addition, a complete pottery series from Terminal Kerma to Napatan times is still lacking for the region (cf. Phillips and Klimaszewska-Drabot 2005: 119 and Budka 2007a).

This picture, seemingly indicating a scarce occupation of the region, changes during medieval and post-medieval times. Settlements of this period are comprised of both numerous surface finds and large quantities of buildings in dry stonewall technique. In the H.U.N.E. concession area, settlements are composed of stone-built structures (cf. Jackson's "Anag-remains", Budka 2005: 10). Traces of mud-brick walls were preserved only at one location of unclear character and date. ${ }^{7}$ This contrasts considerably with the situation in the neighboring concession area of SARS, where several settlements with mud brick structures have been discovered (Welsby 2003a: 123). These places of occupation and small settlements are most often situated on flat hilltops overlooking the river or set above ancient Nile branches. The dwelling places contain a differing number of dry stone-walled units, from 2 or 3 to $10-15$ buildings. They comprise round and rectangular features with either a single room or with several rooms as well as simple stone rings. A large amount of domestic material was found on the surface - pottery with traces of smoke (cooking ware), animal bones, tools, lithics, baking plates and grinding plates.

Site KIR 054 on Kirbekān Island was studied in detail (Budka 2005b: 77-79, Fig. 7). It illustrates a settlement pattern of small clusters of houses, which include stables and places for animals. The architecture of the stone huts took advantage of the local topography; large natural boulders were incorporated into the dry stonewall technique. The finds at KIR 054 (pottery, spindle whorls, grinders and grinding plates) attest to the dwelling character of the site and its date in the medieval period.

Another settlement of a similar type is one of the highlights of the riverbank survey. Village MS 040 lies quite far in the desert at the foot of the ridge on top of which site MS 039, a stone ring with concentrations of lithics (see above), was found. Different kinds of features, all together six units, were noted here [Fig. 3]. These comprise circular, freestanding huts and rectangular structures built of rubble walls abutting natural rock, as well as single lines of stones and simple stone rings. In two cases, a large stone boulder covered with engravings of camels, was surrounded by a simple stone setting. This relation of shelter-like structures and rock art, especially images of camels, is attested several times in the area (e.g. KN 014, $\mathrm{KN} 029)^{8}$ and it is very tempting to assume that people resting or living in those huts were responsible for the engravings. One may suggest that camels were these people's livelihood or at least that they played an important part in their lives. At MS 040 this scenario is very likely since a small clay-figurine of a camel was found as well. All four legs, the neck and the head as well as the tail are broken off and have not been preserved (Budka 2004b: Fig. 8). The upper part of the hump is missing as well, thus only the rump of the animal is preserved $(3.9 \times 1.9 \times 2.3 \mathrm{~cm})$. A second, very similar piece was found at the peninsula of Umm Domi (UD 005.1) in a comparable context, lying on the surface near a settlement built in dry stonewall technique (UD 003). Again, all four legs, the tip of the hump and the head of the figurine are broken off. The remaining features $(4.1 \times 3.9 \times$ $2.3 \mathrm{~cm}$ ) nevertheless clearly depict a camel (Budka 2004a: 41, Fig. 3 and 2004c: 110, Fig. 7). The fabric of this artifact is different from that of MS 040.1, but similar to that of the common coarseware sherds usually found in these dwellings. This could point to a medieval date for the figurine and

\footnotetext{
${ }^{6}$ KIR 106 might be of Meroitic date, see Budka 2007b.

7 The remains of this heavily eroded rectangular structure made of (burnt) red mud-bricks were documented as site ShS 04.

8 This was already observed by other missions in the area; cf. Welsby 2003a: 20 (site 3-O-2).
} 
fits well with the dating of MS 040 where large quantities of pottery, e.g. MS 040.5 , a decorated rim sherd of a collared vase or cup (Budka 2004c: 110, Fig. 6), and a variety of stone objects were found. The painted rim sherd finds parallels in the Dongola reach, at Hambukol and Old Dongola (Welsby Sjöström in Welsby 2001: 241; form group J50 = Adams 1986: 102, class F12, dating from the early Classical period) and in the Christian fortress of Naga el-Scheima in Lower Nubia (Bietak and Schwarz 1987: 157, Fig. 45, No. 76736).

Animal clay figurines have been found in small numbers at Christian sites in Nubia. ${ }^{9}$ Similar pieces were discovered at Abu Geili and Gebel Moya; these do not represent camels but animals like horses and cattle with prominent humps on their backs (Crawford and Addison 1951: Pl. LV, A). In general, these simple handmade clay figurines are supposed to be children's toys (Addison 1949: 147-148). It is obvious that they do not resemble votive objects and did not serve any cultic purpose (Budka 2004: 42), but even if their identification as toys is correct, it would indicate that the respective animals played a prominent role in the community and its cultural communication. Like the hundreds of rock drawings depicting camels, the figurines discovered by H.U.N.E. illustrate the relationship between people living in these structures and the animal (cf. EvansPritchard 1937: 238 and Klute 2002: 110).

\subsubsection{Christian remains at El-Kanisa (KIR 257)}

"Christian remains" marked on the map of the Geographical Survey of Sudan dating from 1929 were identified in the field and recorded as site KIR 257 (Budka 2004b: Fig. 1; Eigner 2005b: Fig. 1). At present, these remains consist of a shallow kom-shaped mound, measuring approximately $220 \mathrm{~m}^{2}$, situated at a height of $285 \mathrm{~m}$ above the Nile within the borders of the modern arable area near the village El-Kanisa. The name as such means 'church' and in itself indicates some kind of Christian activity in the area (Jackson 1926: 27 and lately Eigner 2005b: 93). The surface was covered with fragments of red bricks, some stone debris and a small amount of medieval potsherds.

Excavations at site KIR 257 were conducted in 2005 (for a detailed report, see Eigner 2005b).

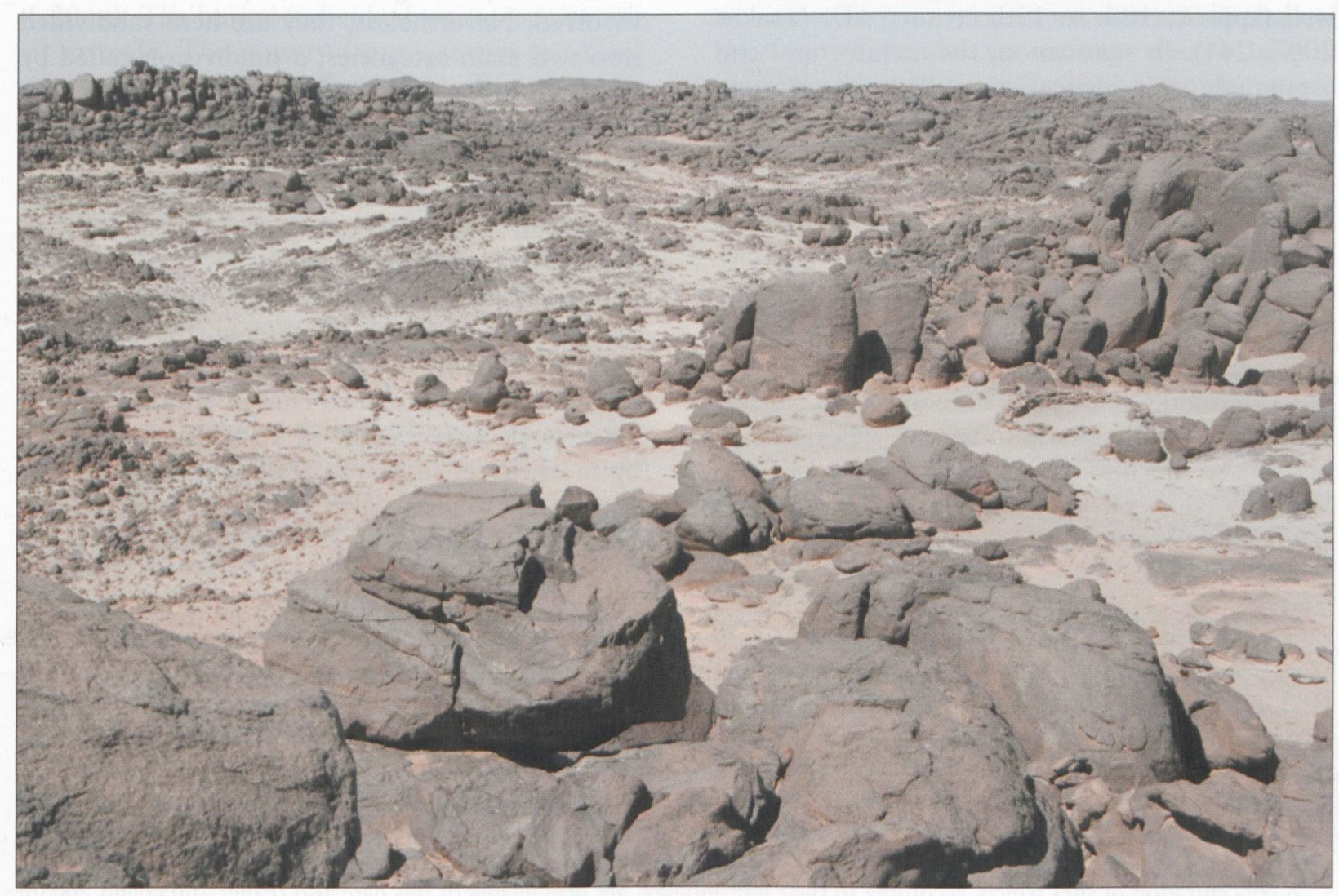

Fig. 3. Stone structures and bolders with rock art at site MS 040 (Photo J. Budka)

\footnotetext{
9 Since none of these figurines has been published, I depend in this matter on oral information kindly provided by colleagues. Some were found at Dongola - for this information I am indebted to S. Jakobielski. As Pawel Wolf told me, also other missions working at the Fourth Cataract have discovered similar pieces.
} 
The debris of red burnt bricks and stones concealed the remains of two parallel walls of mud brick, oriented E-W. These walls belong most likely to the foundations of a church. The mud bricks, which are the only architectural remains of the building, sit on top of a mound of natural soil. ${ }^{10}$ Burnt bricks as the building material other than the mud brick foundations are quite common in Nubian churches (Eigner 2005b: 97).

The debris from KIR 257 yielded some interesting finds: spindle whorls, fragments of a plastered window grille made of mud brick, plaster, ${ }^{11}$ a red brick with finger impressions and fragments of large pottery basins (Sievertsen 2005: Fig. 4). The most remarkable find is a small fragment of a funerary stela with a Greek inscription (Eigner 2005b: 99, Fig. 7). A larger fragment of a similar piece was recovered from the vicinity of the box grave-cemetery KIR 324, which lies just east of the site of the church (for both fragments, see Tsakos 2007: 236). The dating of the site to the Classical and Late Period is largely based on an analysis of the pottery by Uwe Sievertsen (2005). The fragment of the funerary stela points to Classical/Late times as well (approx. 10th to 13th century AD) (Tsakos 2007: 241). In summation, the architectural and topographical evidence, as well as the pottery have definitely established the identification of KIR 257 as a Christian church (see analysis by Eigner 2005b and Sievertsen 2005).

\subsubsection{Funerary remains}

Various cemeteries and graves from differing periods have been recorded. No Neolithic graves have been identified. ${ }^{12}$

The tumuli fields form both lines and clusters and can be subdivided into several types according to the morphology of their superstructures. Stone rings of circular or oval shape appear quite frequently. Conical cairns are also well known. In rare cases, simple circular stone settings of one layer have been observed.

Another common type of tomb is the socalled dome grave, characterized by a "domed chamber raised directly on bedrock" (Paner and Borcowski 2005: 112). Dome graves are funerary constructions characteristic of Cataract areas and landscapes with rocky clefts and outcrops. They are predominantly associated with the Kerma and Napatan periods. There is evidence for this specific type of tomb in all parts of the H.U.N.E. concession. Sometimes they are found in combination with or in close vicinity of Kerma tumulus graves. Some variations within this type of grave structures were recognized. ${ }^{13}$

Cleft-boulder and fissure graves form a separate group but are very often associated with dome graves. Some seem to be contemporary with the latter (Paner and Borcowski 2005: 113, type II.8 crevice graves). In contrast to dome graves, cleft-boulder and fissure graves form no individual structures, but depend largely on the local topography and the natural boulders that are available. Thus, no clear typology for these structures is possible; every single one is slightly different depending on the shape of the boulders involved. Nevertheless, they are here subdivided into two main categories, a subdivision called by Paner and Borcowski "crevice grave" in contrast to "graves formed from natural rock alcoves" (Paner and Borcowski 2005: 113; see Budka 2006: 52). To set a date for the latter is often impossible, as this type of grave was probably in use for a very long period; in Lower Nubia comparable structures were found and assigned to various time periods, including the Christian period (Williams 1990: 43-44).

KIR 236 represents a cluster of dome graves. They were in a very good state of preservation upon discovery in March 2005, but turned out to have been robbed when the team with anthropologists on board arrived to explore them on

10 The natural character of the mound was proved by excavation. Locations on top of a natural hill are typical of Nubian churches, see Eigner 2005b: 99.

11 Cf. Eigner 2005b: 98, Fig. 6; no figural decoration was preserved on the painted plaster fragments.

${ }^{12}$ For a similar picture, see Paner 2003b: 16 and Wolf and Nowotnick 2005a: 186. Wolf and Nowotnick 2005b: 23 suggest surface erosion as one of the reasons for the absence of burial sites from this period. Site KIR 265 in the H.U.N.E. concession might be of Neolithic date, see Jeuthe 2006: 69. In the surveyed strip of land -2 to $3 \mathrm{~km}$ parallel to the Nile and following the major wadis $7 \mathrm{~km}$ up into the hinterland - different types of graves, including tumulus graves, cairns and dome graves, have been recorded from the southern part of the concession at Gebel Musa to Salamat in the north (e.g. KIR 234, KIR 248, KIR 254, KIR 257, KIR 273-275, KIR 294 and KIR 343). These graves are likely of Kerma date. A concentration of sites which, according to their morphology, are presumably of this date also (Paner 2003a and 2003b; Wolf 2004; Paner and Borcowski 2005; El-Tayeb and Kołosowska 2005), was noted on the line between Gebel Musa and Kirbekān. The distribution and location of the Kerma cemeteries show a picture similar to that already known from other concessions. These tombs are frequently located on rocky hilltops towards the desert or on plateaus and slopes of gebels above wadis and the Nile (El-Tayeb and Kołosowska 2005: 53).

13 The dome graves documented during the H.U.N.E. survey are classified into three main types according to their design, construction and location, see Budka 2006: 50-51 and Budka 2007a: 73-77. 
17 February 2006. The central grave of the site (here called Grave 2), the dome of which was still seen intact in 2005, had been dismantled completely. The site was excavated nevertheless in order to clarify the total number of graves. This was set at four dome graves forming a cluster (type Ib). What had looked like a fifth grave ("Grave 1") was remarkably just a structural part of the central Grave 2. Considering its position and the still substantial remains of pottery vessels, it may have been the major burial of this small cemetery.

In the plundered Grave 5, a small poppy-head amulet of carnelian was found (Budka 2006: Colorplate 6). It finds parallels in other dome graves from the Fourth Cataract (cf., e.g., excavations by GAME) (Khartoum 2005: 47), on Middle Nubian-sites (Säve-Söderbergh 1989: 111-112, Pl. 46E), and at the Napatan cemetery of Amara as well. ${ }^{14}$

Grave 6, very similar to Grave 5, is situated $1.10 \mathrm{~m}$ to the west of it and lies adjacent to the central Grave 2. Its dome structure is only visible in the lower layers (diam. approx. $2 \mathrm{~m}$ ). Substantial remains of the burial showed up in an almost central pit just $2 \mathrm{~cm}$ above bedrock $(1.20 \mathrm{x}$ $1.20 \mathrm{~m}$ ). The buried individual was an adolescent or juvenile. The pottery from Grave 6 has close parallels in Grave 2. Several beads of various shapes found in the whereabouts of the neck of the skeleton (KIR 236.21) must have once formed a small necklace.

The pottery has yet to be studied in detail, but it can be said that there are fine wares, which might be imports from the area around Gebel Barkal, and coarser, clearly locally produced wares. Some of the forms recall Kerma types, but of lesser quality, others show distinct shapes (Budka 2006: Fig. 9). The pottery provides dating evidence for the site: KIR 236 can be dated to the transitional phase of Terminal Kerma to Napatan and is most likely contemporary with the Thutmoside period in Egypt. ${ }^{15}$ Despite the modern plundering, the material from the site is important for the study of dome graves and can be used as a representative sample when making comparisons with other sites. An interpretation of KIR 236 as a small clan or family graveyard seems very likely.

During the field reconnaissance in 2005 special attention was paid to site KIR 208 where Napatan pottery was found scattered on the surface [Fig. 4]. Consequently, this small cemetery became the second major excavation site in
2005 (Budka 2005: 76 and Budka 2007a: 78-83). KIR 208 is situated between two rock hilltops at the foot of the gebel south of the village of Umm Meshera (N 18 $56.256^{\prime}$, E 32 $2^{\circ} 24.454^{\prime}$ ). Eight dome and fissure graves, differing in size and construction, were documented. To ascertain the connection of the Napatan pottery with the small group of graves at KIR 208, four examples were excavated. All of the structures had been plundered in ancient times, but two burials were still found in situ (including complete skeletons) as well as the remains of two others with some burial gifts. The finds indicate that KIR 208 had been used during the Napatan period (approx. between $850-600 \mathrm{BC}$ ). The individual tombs are close to one another in date, although Graves 1 and 3 seem a bit older than Grave 2. Since the graves form a small cluster, it is possible that KIR 208 was a family or clan graveyard. Another small assemblage of five dome graves (type Ib, KIR 334) is located on top of the gebel just $20 \mathrm{~m}$ south of KIR 208, literally overlooking the site. KIR 334 closely resembles KIR 236. Therefore, it is to be regretted that possible models of kinship and the chronological relationship between the neighboring sites KIR 208 and KIR 334 could not be tested by excavation and anthropological analysis of the skeletal remains due to lack of time. In analogy to KIR 236, KIR 334 would represent an earlier type of grave, whereas KIR 208 is typically Napatan.

Like KIR 236, KIR 208 displays a tradition of two-level burials, which can be associated with dome graves of type III. According to the evidence from grave 2 of KIR 208, the upper level was probably used for the deposition of grave goods

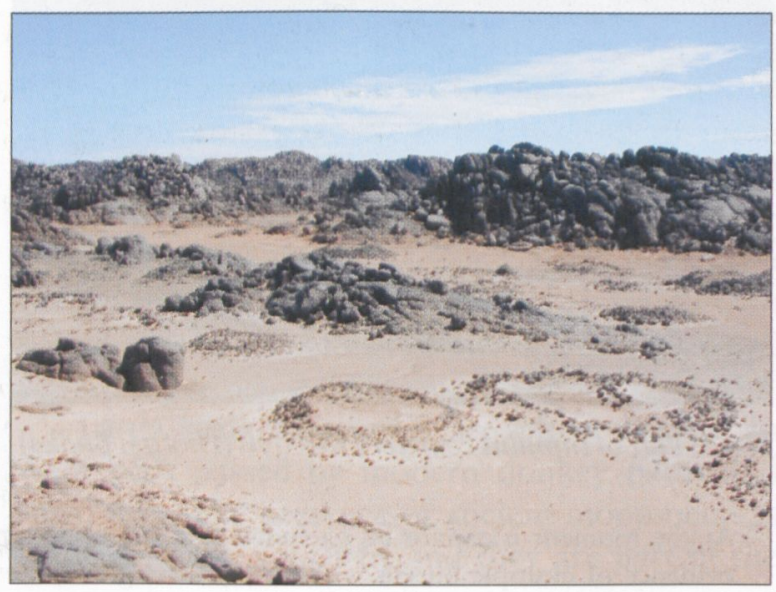

Fig. 4. Cemetery KIR 208, overview looking southeast (Photo J. Budka)

14 Spencer 2002: 5, Pl. $17 \mathrm{~m}$. This type of floral bead is also well attested during the Eighteenth Dynasty in Egypt, see Patch 2005: 206-207, Cat. 125a and b.

15 Egyptian imports for a precise dating are missing - they may have been looted by those who plundered the tomb in the meantime. 
(pottery vessels like KIR 208/16), whereas the lower level, sealed by the stone cover, was the original burial level. ${ }^{16}$ No general rules for the orientation of the bodies could be observed. Similarly as in Sanam, both extended and contracted burials are attested - without notable difference concerning the equipment (Geus 1991: 69). This is a remarkable feature concerning the cultural tradition and burial customs of dome graves. In this respect, the pottery found in the graves is of special importance as well. Two traditions are notable - a local ceramic tradition with coarse, handmade wares clearly related to Kermahorizon pottery but of lower quality (Welsby 2003b: 32) and an Egyptianizing tradition with wheel-made vessels in slightly different fabrics, wares and forms. ${ }^{17}$ These two traditions, as well as all vessels from KIR 208, find close parallels in Napatan cemeteries further downstream.

The post-Meroitic period is again considerably well attested and mostly represented by means of tumuli of different shapes and sizes that had been set in the sandy beds of large wadis. A particularly large tumulus cemetery north of El-Kunaisa (KIR 090) comprised altogether 128 graves [Fig. 5]. This site is of special importance since various types of graves are attested and the surface finds range from the Neolithic to medieval times, including some Kerma moyen sherds. Most of the graves fall into categories III, IV and VI (according to Welsby 2003a: 122) and

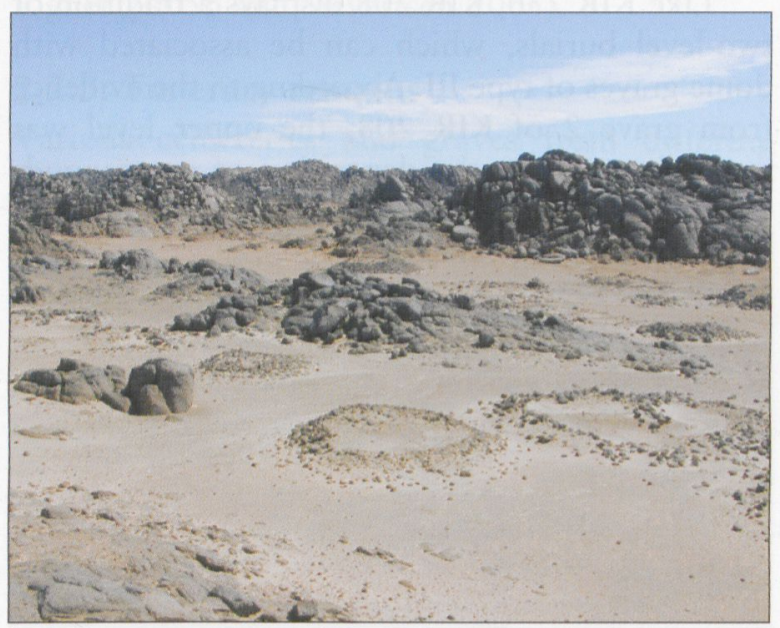

Fig. 5. Part of tumulus cemetery KIR 090 (Photo J. Budka) can be dated securely to the post-Meroitic period. A similar, smaller cemetery of the same period is situated to the south of KIR 090, also in the bed of a major N-S-wadi in the region. It was recorded as KIR 092 and comprises about 60 graves, including four small-scaled box graves on the western edge of the site. The majority of the tombs can be described as gravel-covered mounds with diameters between 9 and $16 \mathrm{~m}$ (types III, IV and VI according to Welsby). These are less well preserved than in KIR 090 - maybe partly because the current desert road runs right through the site.

Several other cemeteries and isolated tumuli were found on the sandy plain of Walad Sabir (MN 012-14), quite far from the river and cultivated land, and close to the modern track. All of them are destroyed and have been robbed very recently, but traces survive. A few insignificant sherds were collected from the surface. A remarkable group of tumuli (at least three structures), the shape of which may be described as ovoid, was recorded as site MN 014. These graves are of Welsby's tumulus type IV which is a characteristic feature of the region (Welsby 2003a: 122).

Cemeteries of the medieval period are numerous in the area and occur mainly as box graves. They were found in different locations: near the riverside and near cultivated land ${ }^{18}$ as well as in the wadi beds ${ }^{19}$ and on plateaus further into the stone desert and hinterland. ${ }^{20}$ At the sites located in wadi beds, a combination of medieval box graves and post-Meroitic tumuli is often attested (e.g. KIR 090, KIR 092, KN 03). KN 03 is situated in Wadi Kereiti and now comprises 50 box graves and more than 20 tumulus graves the original number of both types of graves had been much higher in ancient times. ${ }^{21}$

Quite frequently, modern Islamic graveyards lie adjacent to Christian ones. This is illustrated in the vicinity of Kirbekān by KIR 214, a Christian cemetery that comprises 39 box graves of Welsby's type 4. Judging from the differing sizes of the graves, both adults and children were buried at the place. A modern cemetery is situated to its east and the Muslim graves follow the Christian ones in orientation. Thus, site KIR 214

${ }^{16}$ At the moment it cannot be excluded that the upper level was used for burials as well, since the Polish mission found evidence of multiple burials within one dome grave; see Paner and Borcowski 2007: 4.

17 No Egyptian imports of the Napatan period have been found as of the writing of this report. In the SARS concession, Egyptian vessels were found associated with burials of the Kushite period, see Welsby 2005a: 161 ("including imported wares from Egypt and other in Kerma tradition").

18 E.g. site SA 01 and site MS 001 where several rows of box graves and a single, robbed tumulus can be found.

19 E.g. sites KN 003 and MS 031, both large cemeteries set in the alluvium of ancient water channels.

20 E.g. site ShS 02, a group of approximately 15 box graves featuring common dimensions of $2.50 \times 0.90 \mathrm{~m} \times 1.00 \mathrm{~m}$. This cemetery is oriented N-S, which is remarkable and probably due to the course of the river in this area south of Shellal.

${ }^{21}$ KN 03 was already recorded by the French expedition in 1989, see Montluçon 1994: 310, Fig. 4 and Budka 2005 b: 11. 
illustrates the close relationship, vicinity (and symbiosis?) of Christian and Islamic cemeteries in the area of the Fourth Cataract, something already made obvious by numerous other examples (Kammerzell 2004: 101-102).

Miscellaneous funerary monuments were recorded as well. In most cases, the date and the function of the features are unclear. Attempts to interpret them as graves remain tentative as long as the sites are not excavated. The miscellaneous character of such sites is best demonstrated by ShN 029, situated on top of a small hill in the hinterland of Salamat [Fig. 6]. The site comprises 18 features which can be subdivided into at least four categories:

(1) Two tumuli with stone kerbs of about 80$100 \mathrm{~cm}$ in width and diameters of $4.5 \mathrm{~m}$ and $5 \mathrm{~m}$ respectively. The larger one is still preserved to a height of $1 \mathrm{~m}$. These graves can be assigned tentatively to the Kerma horizon by their type, which corresponds to concentrations of sherds of this period scattered over the surface of ShN 029.

(2) One typical cist grave, which measures 1.4 × $0.9 \times 0.8-0.9 \mathrm{~m}$ and represents a slab-lined stone box. ${ }^{22}$ Another, smaller stone box is located nearby and measures 1 × $0.6 \times 0.4-0.5 \mathrm{~m}$. Although these features might be regarded as funerary monuments, their function remains unclear. Since the cists are relatively small, they could have been ossuaria as well.

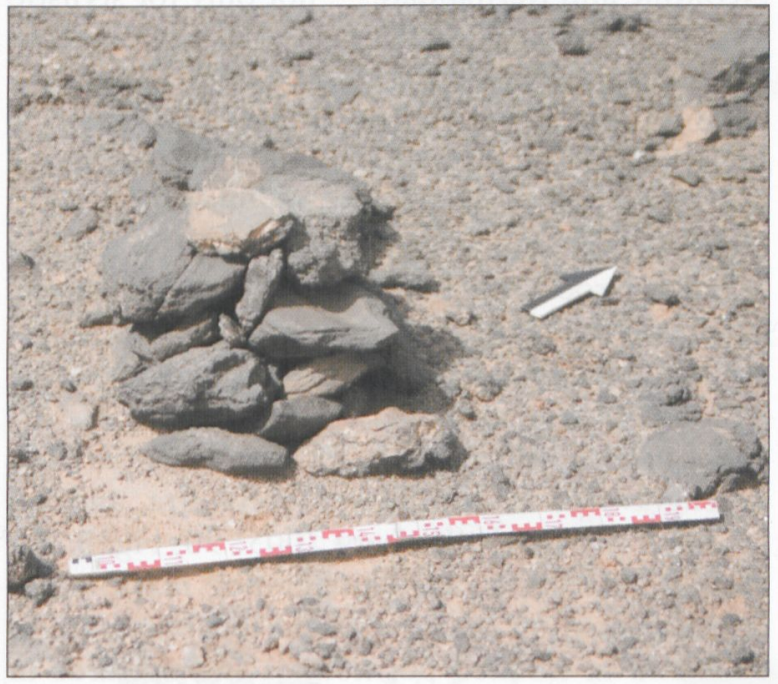

Fig. 6. Miscellaneous stone structure at ShN 029 (Photo N. Staring)
(3) A kind of semi-dome grave. It is a stone circle set in front of a boulder. Next to it, a small solid stone heap of unclear function was recorded.

(4) Stone heaps. Altogether, 13 stone heaps of differing sizes $(0.6 \times 0.4 \times 0.2 \mathrm{~m}$ up to $1.2 \times 1 \times$ $0.8 \mathrm{~m}$ ) were documented spread over the hill [cf. Fig. 6]. Some are arranged in a kind of line, others, near the cist grave, form a kind of semicircle. These features, of which some are too small to have held real burials, find parallels in other concession areas of the region ${ }^{23}$ and in the H.U.N.E. concession in the hinterland of Kereiti (site KN 048). ${ }^{24}$ One might be tempted to assume that the stone heaps in question represent some kind of mark in connection with offerings or with the funerary cult. But since no test digging took place, their function remains obscure.

In summation, the insights from the H.U.N.E. survey on the mainland confirm the results by Welsby, Wolf, Paner and others regarding the typologies of tumulus graves, box graves and other grave types (for these typologies see Welsby 2003a: 122-123 and 2005a: Figs 2-3; Wolf 2004: 21 and Paner and Borcowski 2005: 110 113 , Figs $36-37$ as well as the still unpublished MDASP typology established by Welsby and Borcowski in November 2006).

\subsubsection{Reuse of ancient monuments}

One of the questions which H.U.N.E. and especially the subproject working on the architecture and culture of the Manasir wanted to address is the way in which ancient monuments are integrated into the daily life of the present inhabitants of the region. There are many hints indicating an astonishingly long lifespan of various cultural practices, for example the making of rock engravings or rock graffiti (Kammerzell 2004: 102). In many places, recent engravings of donkeys and camels were found next to more ancient rock drawings (for depositions at and modifications and re-use of rock art localities, see Kleinitz and Olsson 2005: 37-38). Modern graffiti giving personal names and dates tend to be found close to concentrations of rock art of different periods as well. ${ }^{25}$

Large scale cemeteries are often situated in wadi beds passed by modern donkey paths and car tracks. The presence of ancient monuments is evident to any passer-by and they are part of the

22 A comparable cist or tunnel grave with an almost intact cairn was recorded as KIR 005, see Budka 2005b: 73, Fig. 2 (erroneously labeled there as a "dome grave").

23 El-Tayeb and Kołosowska 2005: 55: "Occasionally, next to the grave superstructure stood a small stone cairn (El-Argub, Wadi Umm Rahau), the purpose of which is unclear".

${ }^{24}$ A combination of Kerma tumuli, dome graves, cist graves and stone heaps, see Budka 2007b: 64-65.

25 E.g. site MS 002 with 14 depictions of camels with and without rider and two Arabic graffiti, see Kammerzell 2004: 102 and Budka 2005a: 16. 
cultural landscape of the modern Manasir even more than the rock drawings. In many cases, the ancient monuments are destroyed in a rather careless way in order for cars or donkeys to pass. The situation holds true for all types of graves, for post-Meroitic tumulus graves as represented by KIR 092 and for Christian box graves as well (e.g. KIR 186 at the edge of Wadi Kirbekān). In other cases, post-Meroitic cemeteries were reused in Islamic times, especially for infant burials (Näser 2004: 121; Näser 2005: 55 and Wolf and Nowotnick 2005b: 30). The same can be observed in the case of medieval box grave cemeteries frequently modern Islamic graveyards lie adjacent to Christian ones (see above). In addition to these long traditions of using specific landscape features as graveyards notwithstanding major cultural and religious changes, there are examples that testify to modern reinterpretation of ancient funerary monuments. In the region of the Fourth Cataract, a number of tumulus graves of the post-Meroitic period have been transformed into places of worship of Islamic holy men (baniya). ${ }^{26}$

Site MN 013, an isolated ring-tumulus of roughly round form situated in Walad Sabir [Fig. 7], had been reused and remodeled as well (Kammerzell 2004: 102; Budka 2004c: 107 and Budka 2005a: 13). Stones were erected vertically on its eastern and western sides. Close to the eastern stela-like stone, the surface is littered with recent sherds. In addition, intact handmade pottery vessels of common coarse household wares were deposited, many with smoke traces. The local lore is that women wishing to become pregnant come to this monument, pray and offer

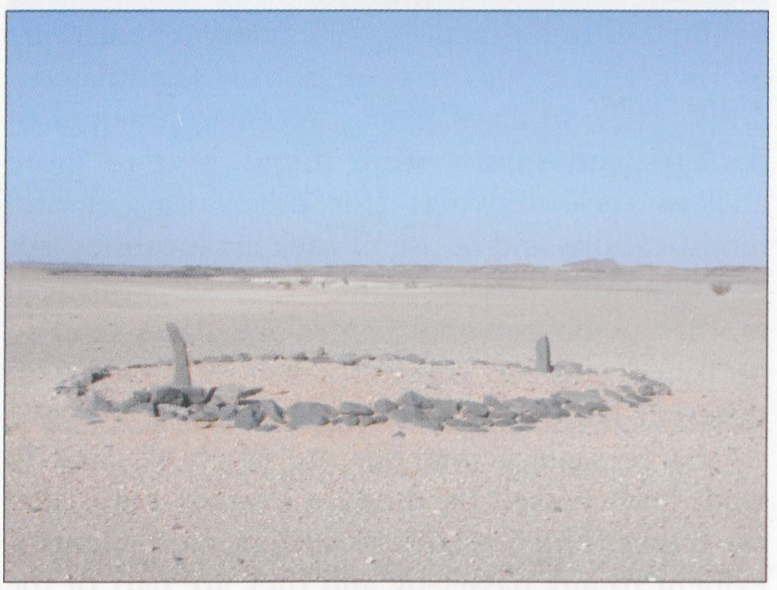

Fig. 7. Site MN 013 remodeled as a baniya in modern times (Photo J. Budka) food and drink. These offerings can be partaken off by all passersby in need and are believed to bring good luck to their donors. Thus, in its latest phase of use MN 013 functions more or less like a baniya where women address their wishes and hopes to a holy man.

\subsubsection{Rock art}

Rock art localities are among the most common types of sites found in the Fourth Cataract region. The total number of individual rock drawings recorded on 172 sites on the H.U.N.E. mainland is about 1650 . Five main groups of motifs can be defined [Fig. 8]: ${ }^{27}$

(1) symbols, objects and architecture (crosses and various other forms, ships and churches),

(2) animals (bovid, camel, equid, caprid, canid etc.),

(3) animals with riders (mostly camel and equid),

(4) animals with drovers (mostly camel), and

(5) humans (hunting and fighting scenes).

Different techniques can be observed on the rock engravings; pecked pictures in both outline and filled technique occur, not seldom with the same motifs (e.g. camels drawn in outline and solid camels) (Welsby 2003a: 111).

In general, rock art provides considerable difficulties in dating and in many cases can hardly be attributed to a specific period with certainty. Although some of the rock art is very likely of Neolithic and Kerma-date - not only for stylistic reasons or because of the nature of the depicted motif, but mainly because of relationship with neighboring Kerma sites (Budka 2005b: 75, Fig. 4), the bulk of the material has been assigned to the Christian and post-medieval period. ${ }^{28}$ However, it should be stressed that the large corpus of rock engravings contains a few motifs expected to be of Meroitic origin. This holds especially true for one drawing of a cow depicted with a bell around its neck (KIR 028.11, Fig. 8) and a particular herding mark that finds parallels in engravings at Musawwarat el-Sufra and on Meroitic potsherds (Karberg 2005: 90, Fig. 3 and Budka 2007b: Fig. 1). This herding mark is not only depicted on the cow's hind leg, but can also be found in isolated position, facing upwards in front of the tableau with the cow-representation.

The rock art found in 2004 in the area north of Kereiti was clearly dominated by images of camels; other animal motifs were scarce (Budka

26 E.g. a tumulus on the island of Us, see Näser 2005: 55-56. For the baniya near Kirbekān and general information on the nature of these installations, see Weschenfelder 2006: 84 with literature in note 12.

27 Cf. motif types classified by Welsby 2003a: 111: vegetation, symbols, animals, humans, animals with riders. On the motif corpus of the SARS concession, see most recently Kleinitz \& Koenitz 2006: 34

28 A similar date was proposed for the rock art recorded in the Dar el-Arab region, see Kleinitz and Olsson 2005: 38. 


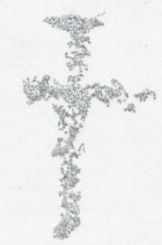

KIR $146.5 \quad 0 \quad 10 \mathrm{~cm}$
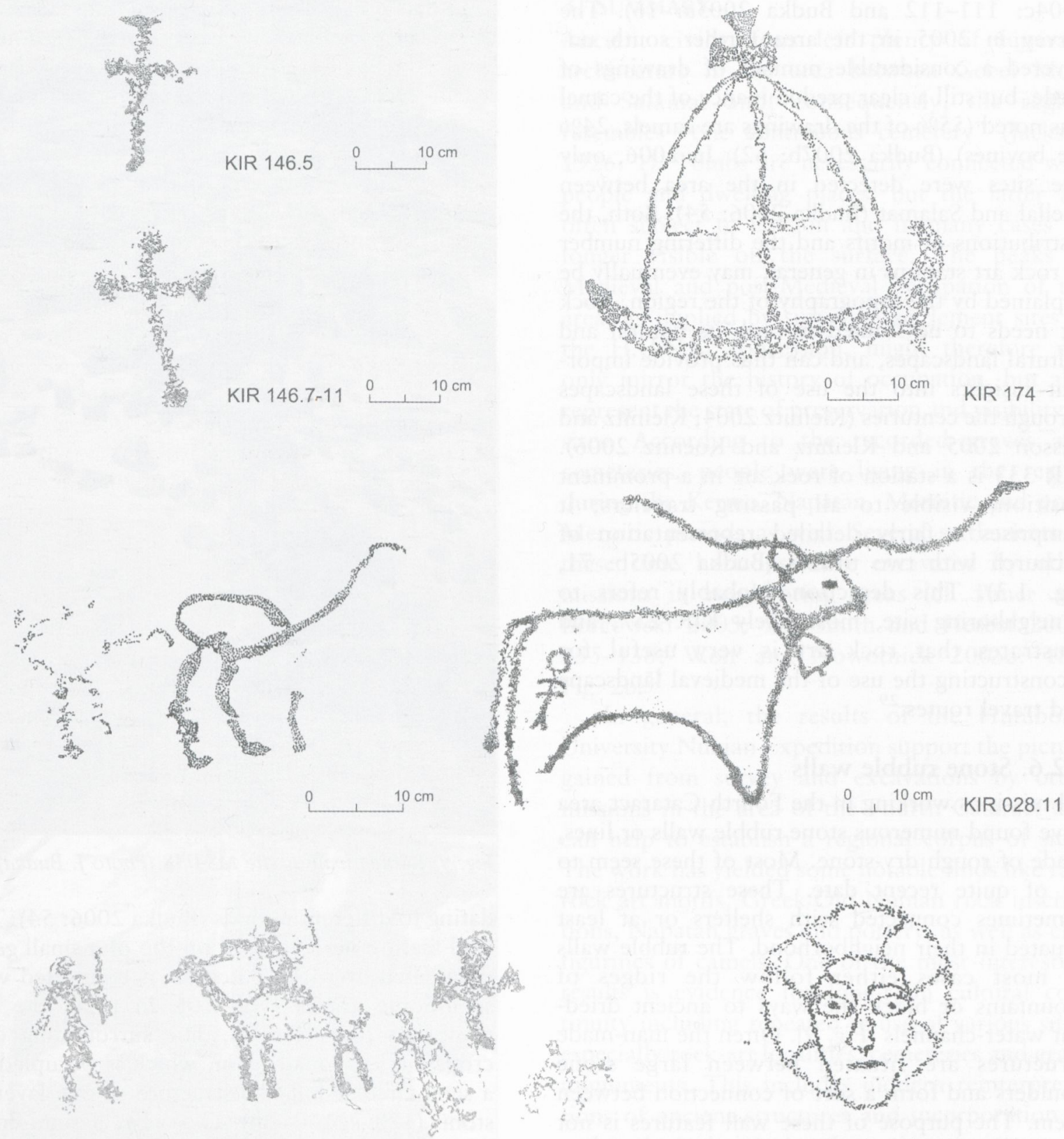

$\stackrel{0}{0 \quad 10} \mathrm{~cm} \quad$ KIR $146.7-7$
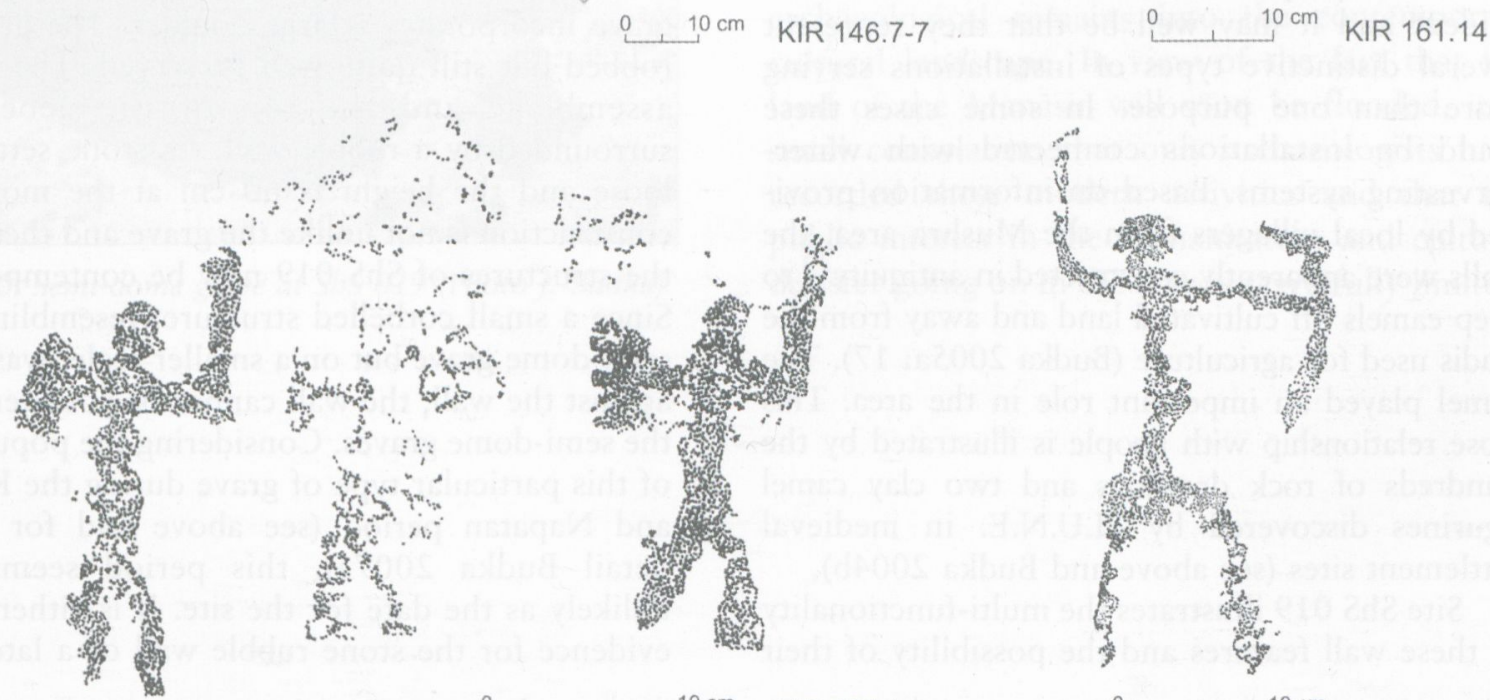

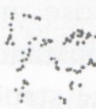

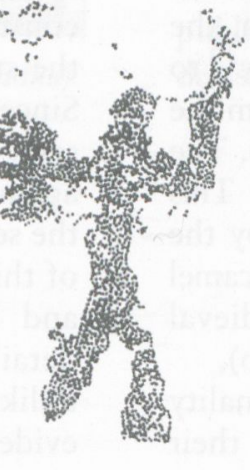

$10 \mathrm{~cm}$

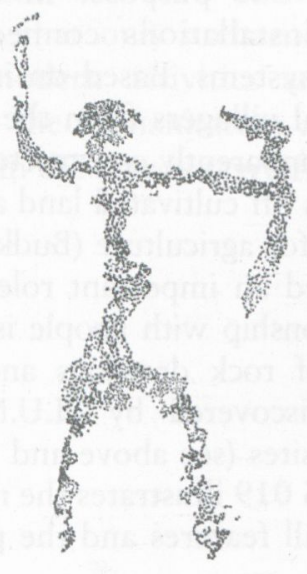

0

$10 \mathrm{~cm}$ KIR 79.1

Fig. 8. Selected rock art motifs from the H.U.N.E. concession 
2004c: 111-112 and Budka 2005a: 16). The survey in 2005 in the area further south uncovered a considerable number of drawings of cattle, but still a clear predominance of the camel was noted $(55 \%$ of the drawings are camels, $24 \%$ are bovines) (Budka 2007b: 62). In 2006, only five sites were detected in the area between Shellal and Salamat (Budka 2006: 54). Both, the distributions of motifs and the differing number of rock art stations in general, may eventually be explained by the topography of the region. Rock art needs to be studied in both its natural and cultural landscapes, and can thus provide important insights into the use of these landscapes through the centuries (Kleinitz 2004; Kleinitz and Olsson 2005 and Kleinitz and Koenitz 2006). KIR 333 is a station of rock art in a prominent position, visible to all passing travelers; it comprises a fairly detailed representation of a church with two towers (Budka 2005b: 71, Fig. 1.3). This depiction probably refers to a neighboring site, most likely KIR 257, and illustrates that rock art is very useful for reconstructing the use of the medieval landscape and travel routes. ${ }^{29}$

\subsubsection{Stone rubble walls}

All missions working in the Fourth Cataract area have found numerous stone rubble walls or lines, made of rough dry-stone. Most of these seem to be of quite recent date. These structures are sometimes connected with shelters or at least situated in their neighborhood. The rubble walls in most cases either follow the ridges of mountains or block the ways to ancient driedout water-channels [Fig. 9]. Often the man-made structures are situated between large stone boulders and form a sort of connection between them. The purpose of these wall features is not evident and it may well be that they represent several distinctive types of installations serving more than one purpose. In some cases these could be installations connected with waterharvesting systems. Based on information provided by local villagers from the Mushra area, the walls were apparently constructed in antiquity ${ }^{30}$ to keep camels off cultivated land and away from the wadis used for agriculture (Budka 2005a: 17). The camel played an important role in the area. This close relationship with people is illustrated by the hundreds of rock drawings and two clay camel figurines discovered by H.U.N.E. in medieval settlement sites (see above and Budka 2004b).

Site ShS 019 illustrates the multi-functionality of these wall features and the possibility of their

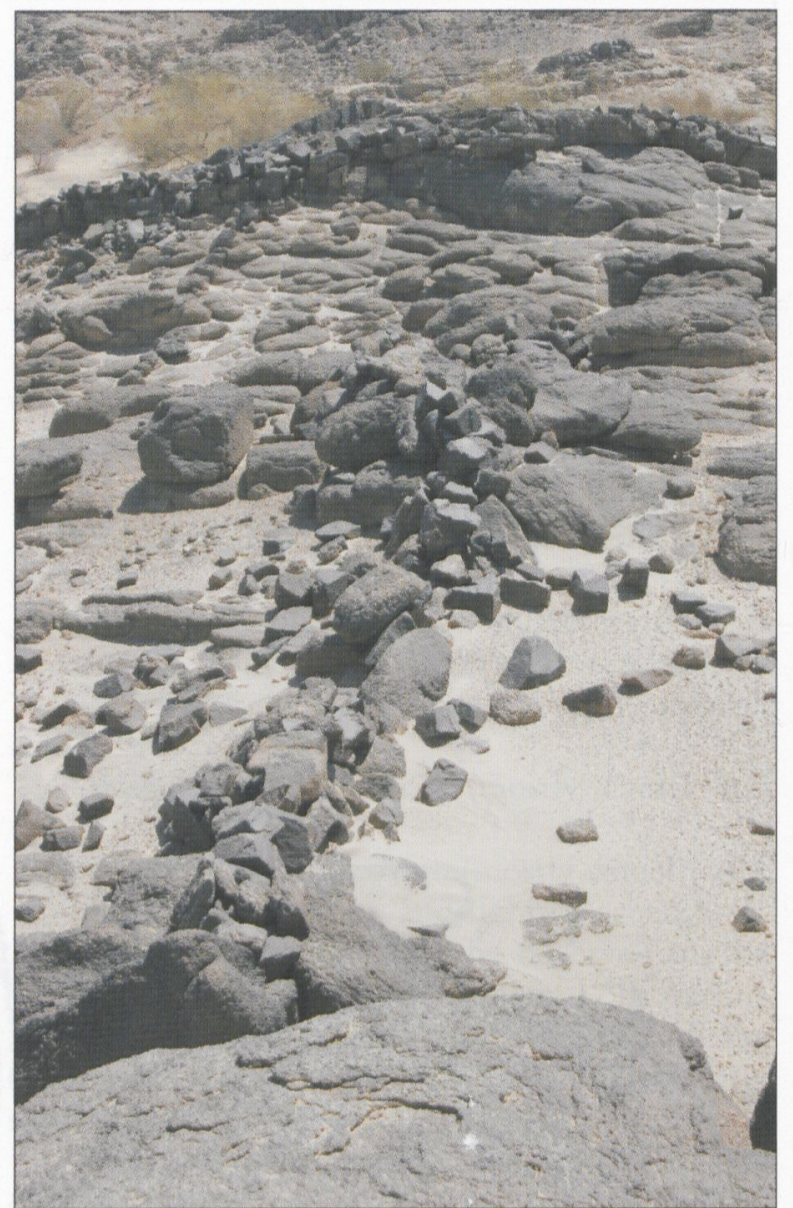

Fig. 9. Rubble wall at site MS 038 (Photo J. Budka)

dating to different periods (Budka 2006: 54). The wall feature here, located on top of a small gebel dominated by rocky outcrops, is connected with semi-dome graves [Fig. 10]. In total, the site comprises four features. The surrounding outcrops circle a small plain, which is occupied by a semi-circular hut-like structure of one layer of stone $(170 \times 160 \mathrm{~cm})$. Close by, a semi-dome grave incorporates a large boulder. The grave is robbed but still quite well preserved. The entire assemblage and the top of the gebel are surrounded by a rubble wall. Its stone setting is loose and the height is $60 \mathrm{~cm}$ at the most. Its construction is not unlike the grave and therefore the structures of ShS 019 may be contemporary. Since a small corbelled structure, resembling the semi-dome grave but on a smaller scale, was built against the wall, the wall cannot be younger than the semi-dome graves. Considering the popularity of this particular type of grave during the Kerma and Napatan period (see above and for more detail Budka 2007a), this period seems not unlikely as the date for the site. It is either early evidence for the stone rubble wall or a late date

29 Rock drawings of camels are especially common along (modern) trails and paths; see Budka 2005a: 17.

30 The term "antiquity" in this context could mean various time periods up to the last century. 
for the types of tombs. In any case, it seems obvious that the stone wall of ShS 019 had a rather symbolic function.

Although the general corpus of sites in the Fourth Cataract area and their presumable dating was established after three seasons of work, it is on the other hand striking that individual sites like ShN 029 never fail to surprise and that, as a rule, it really needs excavation to understand the nature and exact date of the archaeological remains in question.

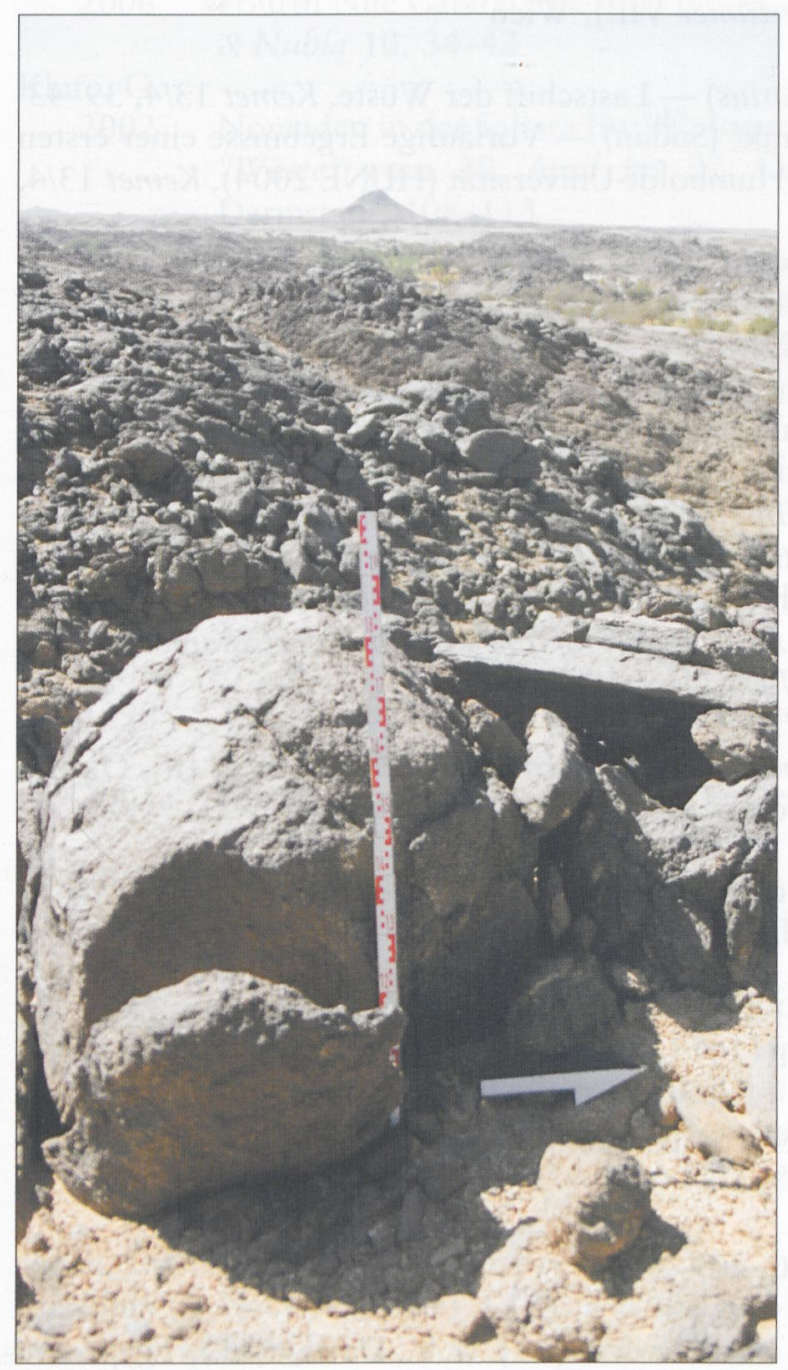

Fig. 10. Semi-dome grave at ShS 019 (Photo J. Budka)

\section{SUMMARY}

Ancient civilizations left plenty of funerary architecture in the area between Gebel Musa and Salamat and, consequently, the region resembles "one continuous cemetery" (Jackson 1926: 1). Tombs are necessarily connected with people and dwelling places, but the latter are often subject to erosion and in many cases no longer visible on the surface. The peaks in Medieval and post-Medieval occupation of the area, as implied by surviving settlement sites in the H.U.N.E. concession, might therefore not only mirror the history of occupation, but also represent the state of preservation and visibility of sites. According to the recorded graves and cemeteries, people were living in the region during the Kerma, Napatan, Meroitic and postMeroitic periods as well. Several settlements of these time horizons were excavated by other missions in neighboring areas (cf. Paner and Borcowski 2005: 98; Smith and Herbst 2005: 135-138; Wolf and Nowotnick 2005a: 183, Fig. 2b. ${ }^{31}$

In general, the results of the Humboldt University Nubian Expedition support the picture gained from survey and excavations by other missions in the area of the Fourth Cataract and can help to establish a regional corpus of sites. The work has yielded some notable finds like rare rock art motifs, Greek/Old Nubian rock inscriptions, Napatan graves and pottery, as well as clay figurines of camels. One of the most interesting results is evidence for long-term cultural continuity including repeated re-use of various sites, especially rock-art localities, cemeteries and grave monuments. This includes modern reinterpretations of ancient structures and incorporation of archaeological remains into the contemporary cultural landscape. In view of the fact that the land of the Manasir will soon be flooded, it is small consolation that only archaeologists have recorded these modern activities and that the public interest in the humanitarian and cultural disaster going on in the area is regretfully limited.

${ }^{31}$ Settlement KIR 106 might be of (Late) Meroitic date, see Budka 2007b. 
Adams, W.Y,

1986 Ceramic Industries of Medieval Nubia, I-II, Lexington, Kentucky

Addison, F.

1949 Jebel Moya [=The Wellcome Excavations in the Sudan I-II], Oxford University Press, London-New York-Toronto

Ahmed, S.M.

2003 Merowe Dam Archaeological Salvage Project (MDASP), MittSAG 14, 73-75

Bietak, M., and Schwarz, M.

1987 Nag' el-Scheima, Eine befestigte christliche Siedlung und andere christliche Denkmäler in Sayala-Nubien, Teil 1 [=Österreichische Akademie der Wissenschaften, Denkschriften der philosophischen Klasse 191, Berichte des Österreichischen Nationalkomitees der UNESCO-

Budka, J. Aktion für die Rettung der Nubischen Altertümer VIII], Wien

2004a Das einhöckrige Kamel (Camelus Dromedarius) - Lastschiff der Wüste, Kemet 13/4, 39-43

2004b Auf der Fährte des Kamels am 4. Nilkatarakt (Sudan) - Vorläufige Ergebnisse einer ersten Feldbegehung der Nubien-Expedition der Humboldt-Universität (HUNE 2004), Kemet 13/4, 69-72

2004c H.U.N.E. 2004, Teil 2: Begehung des Festlands, Der Antike Sudan 15, 105-115

2005a Humboldt-University Nubian Expedition (H.U.N.E.) in Dar al-Manasir: The first reconnaissance survey on the left bank, GAMAR 4, 9-19

2005b H.U.N.E. 2005: Survey und Grabungen in Kirbekān, Der Antike Sudan 16, 69-81

2006 H.U.N.E. 2006: Survey und Grabungen am linken Flussufer, Der Antike Sudan 17, 47-61

2007a Documentation and excavation of dome and cleft-boulder graves in Kirbekān [in:] C. Näser, M. Lange (eds), Proceedings of the Second International Conference on the Archaeology of the Fourth Nile Cataract, Berlin, August 4th-6th, 2005 [=Meroitica 23], Wiesbaden, 73-90

2007b H.U.N.E. 2005: The Kirbekān Survey [in:] C. Näser, M. Lange (eds), Proceedings of the Second International Conference on the Archaeology of the Fourth Nile Cataract. Berlin, August 4th-6th, 2005 [=Meroitica 23], Wiesbaden, 58-72

Crawford, O.G.S., and Addison, F.

1951 Abu Geili; and Saqadi \& Dar el Mek [=The Wellcome Excavations in the Sudan III], Oxford University Press, London-New York-Toronto

Donadoni, S.

1990 Beginning a survey at the Fourth Cataract, Nubica I/II, 153-159

1997 A survey north of the Fourth Cataract, MittSAG 7, 10-22

Eigner, D.

2005a Kirbekān - ein Dorf der Manasir am 4. Nilkatarakt, Der Antike Sudan 16, 113-124

2005b "Christian Remains" - der Fundort KIR 257 am 4. Nilkatarakt, Der Antike Sudan 16, 93-100

2006 Kirbekān - Ein Dorf der Manasir am 4. Nilkatarakt (Teil II), Der Antike Sudan 17, 71-79

Evans-Pritchard, E.E.

1937 Economic life of the Nuer: cattle, SNR 20, 209-245

Geus, F.

1991 Burial customs in the Upper Main Nile: an overview [in:] W.V. Davies (ed.), Egypt and Hakem, A.M.A.

Africa, Nubia from Prehistory to Islam, London, 57-73

1993 Merowe (Hamadab) High Dam and its impact, Kush 16, 1-25

Innes, N.Mcl.

1931 The Monasir country, SNR 14, 185-190

Jackson, H.C.

1926 A trek in the Abu Hamed District, SNR 9, No. 2, 1-35

Jeuthe, C.

2005 Bemerkungen zu den Lithikfunden des Kirbekān-Surveys 2005, Der Antike Sudan 16, 83-87

2006 Prähistorische Fundplätze. H.U.N.E. Survey Festland 2004-2006, Der Antike Sudan 17, 63-70

Kammerzell, F.

2004 Die Humboldt University Nubian Expedition (H.U.N.E.) in Dar al-Manasir - Erster Bericht: Survey 2004, Teil 1: Rahmenbedingungen, Der Antike Sudan 15, 99-103 
Karberg, T.

2005 Bemerkungen zu Rinderdarstellungen in Kirbekān, Der Antike Sudan 16, 89-92

Khartoum

2005 The Gdansk Archeological Museum Expedition 2005: Ten Years in the Sudan, Exhibition catalogue, Khartoum

Kleinitz, C.

2004 Rock art and 'rock gongs' in the Fourth Nile Cataract region: the Ishashi Island rock art survey, Sudan \& Nubia 8, 11-16

Kleinitz, C., and Olsson, C.

2005 Christian period rock art landscapes in the Fourth Cataract region: the Dar el-Arab and etTereif rock art surveys, Sudan \& Nubia 9, 32-39

Kleinitz, C., and Koenitz, R.

2006 Fourth Nile Cataract petroglyphs in context: the ed-Doma and Dirbi rock-art survey, Sudan \& Nubia 10, 34-42

Klute, G.

2002 Nomaden in der Sahara [in:] U. Joger, U. Moldrzyk (eds), Wüste, Begleitbuch zur Ausstellung "Wüste" vom 28. April bis 27. Oktober 2002, Hessisches Landesmuseum Darmstadt, Darmstadt, 108-113

Montluçon, J.

1994 Survey de la region de la IV cataracte du Nil [in:] C. Berger, G. Clerc, N. Grimal (eds), Hommages à Jean Leclant, vol. 2. Nubie, Soudan, Éthiopie [=Institut français d'archéologie orientale, Bibliothèque d'étude 106/2], Le Caire, 309-313

Näser, C.

2004 H.U.N.E. 2004, Teil 3: Bericht über den Insel-Survey, Der Antike Sudan 15, 117-130

2005 Die Humboldt University Nubian Expedition 2005: Arbeiten im Bereich der Inselkonzession, Der Antike Sudan 16, 49-67

2006 Die Humboldt University Nubian Expedition 2006: Arbeiten auf Us und Mograt, Der Antike Sudan 17, 89-116

Paner, H.

1998 The Hamdab Dam Project. Preliminary Report from Work in the 4th Cataract Region, 19961997, GAMAR 1, 115-132

2003a Kerma culture, rock art, dome graves and other discoveries in the Fourth Cataract Region, GAMAR 2, 163-183

2003b Archaeological Survey on the Right Bank of the Nile between Kareima and Abu Ahmed: a brief overview, Sudan \& Nubia 7, 15-20

Paner, H., and Borcowski, Z.

2005 Gdańsk Archaeological Museum Expedition. A Summary of Eight Seasons' Work at the Fourth Cataract, GAMAR 4, 89-115

2007 Dome graves and other uncommon constructions from the Fourth Cataract region [in:] C. Näser, M. Lange (eds), Proceedings of the Second International Conference on the Archaeology of the Fourth Nile Cataract, Berlin, August 4th-6th, 2005 [=Meroitica 23], Wiesbaden, 1-10

Patch, D.C.

2005 Necklaces [in:] C.H. Roehrig (ed.), Hatshepsut: From Queen to Pharao, New York, 204-207

Phillips, J., and Klimaszewska-Drabot, E.

2005 Saffi Island, 2004: an overview of the ceramics, GAMAR 4, 117-123

Säve-Söderbergh, T.

1989 Middle Nubian Sites [=The Scandinavian Joint Expedition to Sudanese Nubia 4:1-2], Uddevalla

Sievertsen, U.

2005 Die christliche Keramik aus der Grabung in KIR 257 (H.U.N.E. 2005), Der Antike Sudan 16, $101-112$

Smith, St.T., and Herbst, G.

2005 The UCSB West (Left) Bank Archaeological Survey from el-Kab to Mograt, GAMAR 4, $133-144$

Spencer, $\mathrm{P}$.

2002 Amara West, II. The Cemetery and the Pottery Corpus, London 
El-Tayeb, M., and Kołosowska, E.

2005 Burial traditions on the right bank of the Nile in the Fourth Cataract region, GAMAR 4, $51-74$

Tsakos, A.

2007 On the medieval inscriptional material from M.D.A.S.P. [in:] C. Näser and M. Lange (eds), Proceedings of the Second International Conference on the Archaeology of the Fourth Nile Cataract, Berlin, August 4th-6th, 2005 [=Meroitica 23], Wiesbaden, 235-246

Welsby, D.A.

2001 Life on the Desert Edge, Seven thousand years of settlement in the Northern Dongola Reach, Sudan, vols I-II [=BAR International Series 980, Sudan Archaeological Research Society Publication 7], London

2003a Survey above the Fourth Nile Cataract [=BAR International Series 1110, Sudan Archaeological Research Society Publication 10], Oxford

2003b The Amri to Kirbekān Survey: the 2002-2003 season, Sudan \& Nubia 7, 26-32

2004 The Merowe Dam Archaeological Salvage Project. The SARS Amri to Kirbekān Survey. Excavations at the pyramid, Site 4-F-71, Sudan \& Nubia 8, 2-3

2005a The Merowe Dam Archaeological Salvage Project. The Sudan Archaeological Research Society's Concession, GAMAR 4, 157-165

2005b The Merowe Dam Archaeological Salvage Project. Survey in the vicinity of ed-Doma (AKSE), 2004-2005, Sudan \& Nubia 9, 2-8

Welsby, D.A., and Davies, V.

2002 Uncovering Ancient Sudan. A Decade of Discovery by the Sudan Archaeological Research Society, Sudan Archaeological Research Society, London

Weschenfelder, P.

2006 H.U.N.E. 2006: Alltagsleben der Frauen im Dorf Kirbekān, Der Antike Sudan 17, 81-88

Williams, B.B.

1990 Twenty-Fifth Dynasty and Napatan Remains at Qustul: Cemeteries $W$ and $V[=$ The University of Chicago Oriental Institute Nubian Expedition VII], Chicago, The Oriental Institute of the University of Chicago

Wolf, P.

2004 The SARS Anglo-German Expedition at the Fourth Cataract of the Nile: the 2003/04 season, Sudan \& Nubia 8, 17-26

Wolf, P., and Nowotnick, U.

2005a First Season of the SARS Anglo-German Survey at the Fourth Cataract, GAMAR 4, 181-198

2005 b Second Season of the SARS Anglo-German Expedition to the Fourth Cataract, Sudan \& Nubia 9, 23-31 